Portland State University

PDXScholar

1974

\title{
An Evaluation of Direct Services of Delaunay Institute for Mental Health
}

Jeanette Anderson Finley

Portland State University

Gary W. Smith

Portland State University

Follow this and additional works at: https://pdxscholar.library.pdx.edu/open_access_etds

Part of the Social Work Commons

Let us know how access to this document benefits you.

\section{Recommended Citation}

Finley, Jeanette Anderson and Smith, Gary W., "An Evaluation of Direct Services of Delaunay Institute for Mental Health" (1974). Dissertations and Theses. Paper 1714.

https://doi.org/10.15760/etd.1713

This Thesis is brought to you for free and open access. It has been accepted for inclusion in Dissertations and Theses by an authorized administrator of PDXScholar. Please contact us if we can make this document more accessible: pdxscholar@pdx.edu. 


\title{
AN BVALUATION OP DIRBCT SERVICES OF \\ DEIAUNAX IMSTITUTE FOR MEYTAL HEALTH
}

\author{
by \\ JEANETTE ANDERSON FINLEY \\ CARY W. SYITH
}
A report submitted in partial fulfillmont of the requirements for the degree of

\author{
MASTER OF \\ SOCIAL WORK
}
Portland State UnIveraity
1974

Frank P. Mlles, Ph.D., Chairmen 
TABLE OF CONTENTS

PAGE

IIST OF TLBLES ........................... 111

SECIION

I INTRODUCTION. .................. I

II SETTING ................... 4

III NATURE OF THE PROBLFY . . . . . . . . . . 6

IV DESIGN. . . . . . . . . . . . . . . 8

The Test Instrument ............ 8

Solection of Population and Tost Administration . . 9

V ANALISIS. . . . . . . . . . . . . 12

VI REVIEW OF THE LITRRATURB. . . . . . . . . . . 16

VII CONCLUSIONS AND RECOMATENDATIONS . . . . . . . . 22

REFERTNCES CITED . . . . . . . . . . . . . . . 25

A SELETED BIBLTOCRAPHY. . . . . . . . . . . . . 27

APPENDIX . . . . . . . . . . . . . . . . . . 28 
I Demographic Characterlst1cs of the Sample........ 10-11

II Significance Tests Between Study Sample and Incomplete

Sample on Selected Variabler, . . . . . . . 12-13

III Proportion of Raters Who Saw Pro-Post Improvemant . . . 30

IV Not Positive or Negative Change as Rated by Male and

Female Self and Informant . . . . . . . . . 31

v Self and Informant Pre-Post Ratings on Malo Clients ... 32

VI Self and Informant Pre-Post Ratings on Female Clients . . 33

VII Correlation Coefficients Between Raters . . . . . 34

VII Number of Interviews. . . . . . . . . . . 35 


\section{INTRODUCTION}

Wo live in an age of "accountability." To a social agency this means being responsible for loarning what impact treatment has upon the clients involved and the community in which they live. The following statement reveals pertinent issues and reasons for studying treatment results.

Any social agency supported by taxpayers' money or voluntary funds, has a duty to study and evaluate its effectiveness and to seek continuously to Improve the methods it employs to achieve its objectives. It is not onough to belleve, however sincerely, that we are doing good. It is not enough to invoke experience, or to collect meaningless and misleading information. It is not completely honest to spend money on giving attention to people who do not need such attention, or to those who $\mathrm{might}$ be better integrated with society if they were not disturbed by unsought ministrations of well-meaning people. It is not enough to rely upon the support of colleagues and those in the same professional group and to accept their endorsement of our work 28 proof of its effectiveness. Professional in-group support does not measure effectiveness and does not absolve us from accountability for our decisions. The effectiveness of social agencies, it is claimed, is a question to be determined empirically by methods which can be repeated and verified by others. 1

Today taxpayers (those who pay for services) and clients (those who receive services) wish the best use for the money that they invest. The public is not as accepting of generalities, observations or intuitive success measures of social agencies' performance. Emotional problems are costly. Often they can lead to 1088 of employment, inefficiency, break-up of marriages, retarding the emotional development of children and use of monies invested by other agencies, 1.e., welfare, Juvenile courts, otc. Social agencies, in rosponse to the general 
publ1c, are raising issues around what are appropriate measures for evaluating treatment outcome. The instant study is one such response on the part of Delaunay Institute for Mental Health. The study attempts to ascertain treatment outcone in the Delaunay program and at the same time test out the PARS (Personal Adjustment and Role Skill) as an evaluative instrument in making treatment assessment.

The task of developing a research design is often difficult because we are attempting and often required to find a systematic approach to study people, each of whom has unique characteristics according to his or her own psychological, physiological and cultural influences. Issues arise regarding who should evaluate treatment results, the client or the therapist? Also what considerations are given to such variables as wodes of treatment, therapists' personality and differences in the emotional problems need to be considered. The PARS, as an evaluative instrument, was developed by $\mathrm{Dr}$. Robert EIlsworth $2,3,4$ who was the director of a four year project at the Veterans Administration Hospital in Roseburg, Oregon. The project Involved developing an effective and 1088 complex means to evaluate program effectivenoss. The PARS was designed to meesure the behavioral adjustment of the client in his natural surroundings--the community in whlch he 11ves. Dr. EIlsworth used a "signiflcant other person" (preferably a relative in the same household) in the client's ilfe as a rater. He found, contrary to the assumption that relatives are blased, their ratings were as valld as the hospital otaff ratings of the patient. Ellaworth concluded thet clients behave differently apart from the treatment setting and that if a client relates well to the therapist it does not have significance unless behavioral changes also 
occur in the community. The use of the PARS Scale was chosen significantly by Delaunay Institute for Montal Hoalth to measure the effective ness that their treatment program had upon their clients and the community. 


\section{SBTIINO}

Delaunay Institute for Montal Health 18 a community mental health center located at 6419 N. Portemouth Arenue, Portland, Oregon. The Institute was founded in 1946. Although the clients are primarily from the North Portland area, services are avallable to the entire Portland metropolitan community.

The Center offers clinical services including outpatient treatment, psychological and psychiatric evaluations and consultation to other community agencies. In addition to clinic services it is involved in training of mental health professionals and research activities.

The ataff consists of a psychiatrist-director, a social worker administrator, two psychologists, an ACSW social worker, psychiatric nurse and three clertcal workers. Each staff member (with the exception of the clerical workers) is qualified to perform all clinic functions--diagnosis and treatment.

Modes of treatment are based on the client's needs and the therapist's speciality. Currently treatment offered varies from insight, Gestalt, behavioral reality, crisis intervention, to play therapy for children. Individual, marital, family, and group therapy is offered depending on the client's needs.

Trainees currently on staff are two peychology interns from Washington State UnIversity at Pullman, Washington, and University of Portland, Portland, Oregon. There are four second year graduate students from Portland State University School of Social Work, Portland, 
Oregon.

The research component is the active involvement in evaluating clintcal services as to its effect on the individual and the community. The Clinic 18 part of the Oregon Research Inst1tute that assists in developing measures to assess clinic effoctiveness. Research is regarded as an integral activity of the agency and is encouraged and pursued in numerous other areas. 


\section{NATURE OF THE PROBLEM}

Delaunay Institute is a private mental health service that is contracted by the State of Oregon through the State Division of Mental Health to provide mental health care for the North Portland catchment area. As part of the increased pressures upon agencies for accountability, the state requires funded agencies to be part of the MBO (Management by Objective) process. This process is a systematic approach in assessing effectiveness and output rather than a "generalized" evaluation that was deemed sufficient in the past. Additionally the staff at Delaunay Institute feels a responsibility to their clients and themselves in evaluating the impact of treatment on clients and thus a potential for continuing treatment innovation relevant to the needs of the community.

Staff at Delaunay Institute, after assessing various research deaigns, had chosen the PARS (Personal Adjustment and Role SkdlI) Scale for program evaluation. The PARS Scales focus on the client and the "signiflcant other" person in that client's life, both of which rate the cllent's adjustment and are therefore potential measures of treatment effectiveness.

Dolaunay Institute began administering the pre-PARS questionnaire to each new client or pair of clients (In the case of people who came in for marital therapy) in November of 1972. The PARS questionnaire was given before the first interviow. The Minnosota Multiphastic Personality Inventory was also administered at this time. 
After the first interview, a form giving permission for the release of information was signed by each client. In addition, each client was asked to name a "slgnificant other" in his Iife to which the pre-PARS questionnaire was malled. After completion, the questionnalre was then returnad to Delaunay for scoring.

Delaunay's orfginal research design called for the clients undergoing therapy and the signiflcant others to retake the PARS questionnaire (post-PARS) after throe months of therapy. The plan was to mail the post-PARS questionnaire to the clients and significant others and have them returned by mail after completion for scoring and analysis.

At this point two major diffioulties in the original design became apparent. Contrary to expectations; it was discovered that the majority of the client population that Delaunay had tested since November of 1972 did not remain in therapy for three months. (See Table VIII, Appendix C, page 35.) Second, it was found that several of the pre-PARS questionnaires for both the self and other had not been completed and returned. For the purposes of this study incomplete questionnaires were then eliminated from further analysio.

At this point we found that the original research design was unworkable and that we would need to develop a now one. We felt it was Important to continue to use the PARS questionnaire as efforts had gone into gathering the data. Therefore, we chose to use the PARS in a termination study because we would have some control in establishing the crlteria for the selection of our research population. 


\section{DESION}

As was discussed in the previous section, we were forced to change the focus of our study. Our study rould involve an attempt to assess treatwent outcome for clients who have terminated treatment from Delaunay Institute. "Terminated" cllents rofor to those who are not scheduled for future appointments of ther by mutual agreement between the client and therapist or those clients who have not been seen at Delaunay for the past aix weeks.

\section{The Test Instrument}

The Instrument used for assessing treatment income is the PARS Scale (refer to provious references 2, 3, and 4). The PARS Scale is a 57-1tem questionnalre mosuring seven factor areas, which differ slightly between male and fomale. It is administered to the client and a "signiflcant other" person (preferably a relative in the same household) at the beginning of treatment and at termination of treatment. The seven factors attempt to translate abstract concepts of psychopathology into concrete behaviors that are observable to the raters. The factors for males and examples of concrete behaviors are (1) Interpersonal involvement--shows consideration for and interest in the Igniflcant other; (2) confuaton--108es track of tine; (3) anxiety-difflculty sleeping and eating, foels nervous; (4) agltation-depression-feols upset or feels others don't care; (5) alcohol-drug abuse--drinks to excess or becomes high; (6) employment--1s employed or looking for 
omployment; and (7) outside social--attends activities outside the home. For the female client anxiety is dropped and household management is added--shops, prepares dinner, etc. Bmployment becomes an optional factor and parenthood skills for both male and fomale are optional depending on whether there are children in the household.

\section{Selection of Population and Test Administration}

The criteria developed for inclusion in the research population are: (1) the client must have undergone at least three therapy sessions; (2) the client must have terminated from treatment; and (3) the client mast have terminated between June 1 and September 15, 1973. The last criterion was added because we wanted to measure treatment offects as close to the end of therapy as possible. By implementing these new criteria we obtained a population of 48 patients. Of these, 16 of the pre-PARS had either the self or significant other questionnaire missing. Therefore we did not gather post-PARS data on the 16 patients with incomplete pre-PARS data.

Next we mailed a letter (see Appendix A, page 29) to the remsining clients and their informants along with a copy of the post-PARS questionnaire, explaining that we would call on them soon to arrange for return of the questionnaire. We phoned the remaining 32 clients in two to three weeks and made arrangements to pick up the completed PARS questionnaires. In this way we hoped to get a better response than if we ralled on malled roturne.

Wo encountered numerous problems in obtaining the post-PARS data. Many clients had either lost the questionnaire or had failed to complete 1t. Thirteen of the clients were either uncooperative (in spite of the 
fact that they had signed an agreement stating that they would participate in evaluation at a later date) or we were unable to locate them. We made two to three phone calls to each client and were greated with mixed sentiments. Some clients were open and cooperative; others were evasive. We made home visits to most of the clients and their informants, and a few individuals preferred to mall their responses to Delaunay.

This left a total sample of 19 complete sets of pre and post data. Table I shows the dewographic traits of the 19 patients.

TABIE I

DEMOGRAPHIC CHARACTERISTICS OF THE SAMPIE

$\mathbf{n}=19$

\section{Treatment Category}

Adult Psychiatric

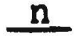

Hospital Follow-up

15

Drug Problem

Marital Counseling

Adolescent

\section{Income}

Under $\$ 3,000$

\begin{tabular}{l} 
n \\
\hline 9 \\
2 \\
1 \\
1 \\
3 \\
1 \\
1 \\
1
\end{tabular}

$\$ 5,000-5,999$

$\$ 6,000-6,999$

$\$ 8,000-8,999$

$\$ 9,000-9,999$

$\$ 10,000-14,999$

$\$ 15,000-19,999$

Over $\$ 20,000$

1 
TABLE I, Continued

Marital Status

\begin{tabular}{lc} 
& $n$ \\
\cline { 2 - 2 } Married Once & 9 \\
Remarried & 1 \\
Married but Separated & 2 \\
Divorced & 4 \\
Never Married & 3
\end{tabular}

\section{Bducetion}

High School or Less 16

Some College or Degree 3

$\begin{array}{lll} & \text { Sex } & n \\ \text { Female } & \text { II } \\ \text { Male } & 8\end{array}$

\section{Ape}

$\bar{x}=32 \quad$ Range $16-46$ 


\section{ANALYSIS}

Since our final number of completed sets of PARS data was small (19) we decided to run throe tests to learn if our population of 19 was representative of the original population of 48 . We tested on factors of age, sex, and self administered pre-PARS Factor "A" (Interpersonal Involvement) scores. We ran F tests on Age and Factor "A" scores and a test for the standard error of the difference between two proportions on sex. Wo chose to look at these three areas because we felt that demographic factors such as age and sex are good bastc indices of "allkeness" and that Factor "A" seemed to us to be an overall measure of social bohavloral runctioning.

\section{TABIE II}

SIGNIFICANCE TESTS BETWEEN STUDI SAMPLE AND INCOMPLETE SAMPLE ON SELECTED VARIABLES

\section{Age}

Complete

$$
\begin{aligned}
& n=19 \\
& \bar{x}=32.37 \\
& =8.53
\end{aligned}
$$

\begin{tabular}{|c|c|}
\hline Complete & Incomplete \\
\hline $\begin{array}{l}n=17 \\
\bar{x}=34.06 \\
\sigma=5.62\end{array}$ & $\begin{array}{l}n=29 \\
\bar{x}=35.79 \\
\sigma=4.84\end{array}$ \\
\hline
\end{tabular}

$$
F=1.57
$$


TABRE II, Continued

$$
\begin{array}{rlr}
\left(p_{1}=\text { proportion of males; } q_{1}\right. & \frac{\text { Sex }}{\text { proportion of females })} \\
\frac{\text { Complete }}{n}=19 & \frac{\text { Incomplete }}{n}=29 \\
p_{1}=.421 & p_{2}=.379 \\
q_{1}=.579 & & q_{2}=.621
\end{array}
$$

On the basis of these three tests, we accepted the null hypothesis in each of them. We concluded that any differences between the 19 complete sets of PARS data and the remainder of our population on these three traits at least were due to chance.

From this point on we confined ourselves to an analysis of the 19 completed pairs of pre- and post-PARS data.

We did an analysis of variance on net change scores for the first three PARS factors. The four groups we analyzed on these factors were the male self and his informant, and the fomale self and her informant. We found that the variance between these groups was not statistically signiflcant at the .05 level on any of these factors. We therefore concluded that we could not say that there was more variation between groups than within groups. In fact, there was considerable variation in individual change scores within groups. In most instances the mafority ( $50 \%$ or more) of the individual self or informant raters saw change in a positive direction.

Nore of the self raters saw positive change than did the informant raters, and in a majortty of the cases, fomale self and informant raters saw more positive change than the males. 
Further eridence of this can be seen in Table III (see Appendix B, page 30). Here we computed the proportions of male and fomale, self and informant raters who saw change in a positive direction on 211 of the PARS factors. Again, we found that when self and informants were combined, regardless of sex, a majority of the raters saw improvement. Howevor, we also found that when wo separated self and informant ratings wore of the self raters saw Improvement than did the informants regardless of sex. And, as before, when sex was taken into account more female self raters saw improvement than male self raters. This did not hold true for the informants.

A sories of $t$ tosts were calculated to determine the statistical significance of our various change scores. As shown in Table IV (see Appendix B, page 31), the direction of change is generally toward Improvement across all the PARS factors, but fow of these figures reach statistical significance. This table quantifies the net direction of change as soen by male and female, self and informant raters. Statistically significant change was found for males in the Outside Social factor and for females in the Confusion factor. The direction of change in both instances was toward improvement.

Tables V and VI (see Appendix B, pages 32 and 33 rospectively) are $t$ tests for the significance of the difference between the mean pro- and post-PARS scoros for male and fomale self and informant raters. Unlike Table IV, these tables are not 1llustrative of the direction of change. They ingtead illustrate the differences between mean pre and post scores. Again, the majority of these figures do not reach statistical signiflcance, so we cannot conclude that the majority of the pre-post mans are significantly different at the .05 level, 
regardless of whether or not the change was in the positive or the negative direction.

Statistically significant differences for men were found for both self and informant raters in the Anxioty factor and for self raters only in the Confusion factor. For forales, the self-rated differences between mean scores for Agitation-Depression, Confusion, and Employment were significant. These were all changes in the positive direction. There were no statistically significant figures for female informants. Table VII (see Appendix B, page 34) summarizes the correlation ( $r$ ) of the agreement between self and informant raters on the pre-PARS and the post-PARS questionnaire. As can be seen, 10 of the 16 correlation coefficients were higher for the post-PARS than for the pre-PARS. The "average agreoment" as measured by a mean of correlations over all factors was higher for males at termination than when treatment began, but it was lower for fomales. Thus, although there was higher agreement on most of the factors at termination, there was much lower agreement on a fow of the other factors, particularly for fomale raters. On the factor with $n$ of 2 , the standard error of the correlation was .14. 


\section{REVIEN OF LITERATURE}

Because we encountered 80 many problems in this study and because we wanted to compare our findings to those that had been obtained in previous studies, we did a short reviow of the Iiterature.

In his article, "The Outcome Problem in Psychotherapy,"5 Dav1d H. Malan, D.M., attempts to summarlze aspects of the history of psychotherapy research, with spectal reforence to dynamic psychotherapy, during the past twenty years. We chose to oxamine this plece of Iiterature because it is one of the most up-to-date and comprehensive articles dealing with psychotherapy research. According to Dr. Malan, a thorough look at the Ifterature reveals that evidence for the effectiveness of psychotherapy is stronger than supposed. However, one difficulty has been integrating research findings with clinical practice.

Dr. Malan claims that psychotherapy research in the early $1950^{\prime} \mathrm{s}$ came up with little in the way of concrete results. Research since then has been much more productive. Nevertheless, unt1l quite recently, research on psychoanalysis 6 has been sparse and inconclusive.

\section{Trende in Psrchotherepr Research. 1952-1971}

The flrst comprehensive study of the cruclal outcome problem was done by Eysenck in 1952.7 His study seemed to show that about twothirds of neurotic patients improved no matter how they were treated or even if they were not treated at all. Naturally, this finding resulted in much criticism, but only recently did this take the form of criticism 
based on scientific re-analysis of Eysenck's original data.

In 1956, Desmond Cartwright wrote a little-noticed article refuting a study done by Barron and Leary which had obtained results similar to Eysenck's. ${ }^{8}$ Cartwright showed that although the average improvement of both treated and non-treated individuals was the same, the variation in improvement between the groups was greater for the treated group. Th1s would 1mply that therapy was causing some individuals to improve greatly while others deteriorated significantly.

Whilo Cartwright's work attracted little attention, five other events related to psychotherapy research were occurring. The first was the Psychotherapy Research Project of the Menninger Foundation' dealing with psychoanalysis and psychoanalytically based psychotherapy. A second was the continued research in client-centered therapy which had been started by Carl Rogers. A third was the series of studies on dynamic paychotherapy at the Phipps Clinic under Jerome Frank. A fourth was the progress of behavior therapy and the fifth was a series of three conferences on Research in Psychotherapy in Washington, D. C. (1958); Chapel Hill, North Carolina (1961); and Chicago (1966).

\section{Conferences on Regearch in Parchotherapy}

An examination of the papers presented at the first conference shows that they were concerned with the process of psychotherapy research than the outcome. However, the second conference contalned four papers dealing with the correlation between outcome and patient and thereplst rariables. In the third conference, the trend once again moved avay. from the outcome problem, doeling instead with behavior therapy and ISD. During this time Strupp complained that research had 
little effect on the practice of peychotherapy. Also during this time, researchers in behavior therapy were able to make advances in quant1fying the success of this form of therapy.

Client-centered researchers also studied therapist variables and found that with schizophrenic patients, therapists favoring "responsible self-determination" rather than "obedience and conformity" were more effective. However, with adult nourotic patients, the results were just the opposite. 10

Rogers, Truax, and later Berginll studied the "deterioration offect" that had been prosent in earlier studies that had shown little positive improvement after psychothorapy. It was shown that some therapists made patients olgnificantly better, and some signiflcantly worse. Therefore, in Iine with Cartwright's 1956 paper, it became apparent that psychotherapy was actually effective in many instances, despite the fact that it was strikingly ineffective or even harmful in others. Truax and Carkhuffl2 were able to identify therapist variables that led to patient improvement. These were nonpossessive warmth, genuineness, and empathy. Absence of these factors led to deterioration.

Bergin's 1966 paper "Some Implications of Psychotherapy Research for Therapeutic Practice"13 was an important contribution to research in the fleld. He concluded that most forms of therapy made patients both worse and better. This accounts for the lack of average improvement found so often in studies comparing treated patients and controls. Ho also found that untreated patiente' syuptoms improved after time. Another concluaion was that the only Interview-oriented therapy that consistently yielded positive results was the client-centered approach. Purther he found that therapist characteristics such as warmth, empathy, 
adequate adjustment, and experience correlated positively with patient improvement. Bergin concluded that some patients are not helped by interview-oriented poychotherapy and some types of symptoma are helped by behavior therapy. However, this all may be said of untreated patients.

Strupp and Bergin's 1969 paper "Some Empirical and Conceptual Bases for Coordinated Research in Psychotherapy"lit considered the cllmate and possibilities for large scale collaborative research. They concluded that although practitioners had taken little heed of research findings in the past, there was an atmosphere conducive to large scale investigation of psychotherapy outcone. They reported the trends as being "a strong reaction against individual one-to-one psychotherapy," the relegation of intrapsychic changes "to the background in favor of behavioral changes," and "an increasing disaffection from psychoanalysis."

In "The Handbook of Paychotherapy and Behavior Change," 15 Bergin re-oxamined Eysenck's figures as well as surveying the literature. He concluded that (1) "spontaneous" Improvement rates were much lower than Eysenck had claimed, actually around 30\%; (2) two major problems in psychotherapy research are (a) what is the quantitative difference between improved and slightly improved and (b) whether or not early drop-outs should be included as therapy fallures. However, according to Malan, it seems that Bergin's figures on spontaneous remission rates are no more reliable than Eybenck's. Malan advocates properly controlled studies.

Moltroff and Kornreich ovaluated 101 research studies in 1970 and found that the majority of these studies supported rejection of the null 
hypothesis, and that in general, the better the quality of the research, the more positive the results obtained. 16 According to Malan, if we accopt marginal evidence as Ejsenck did, we can no longer say that on the average there is no difforence between treated patients and controls. If, however, we require Meltzoff's 101 studies to have a six month follow-up and that treated subjects be both patients (as opposed to volunteors) and adult and non-payohotic, the list is reduced to four. There ware no studies out of the 101 that dealt with adult psychonourotic outpetients. 17

Ending his review of the literature, Malan stated thats (1) "the ovidence for the effectiveness of psychotherapy is now relatively strong"; (2) dyanic psychotherapy is effective in psychosomatic conditions; but (3) the evidence for the ouccess of dynamic psychotherapy In treating nouroses and character disorder "18 weak in the extreme."18

One theme running through all this since the 1950's has been the disillusionment with psychotherapy research in general. Even such eminent poople in the fleld as Carl Rogers, Matarrazzo, Truax, and Strupp and Bergin have expressed such feelings, Bergin stated that positive results could be found if adequate means could be developed.

In contrast to this somewhat pessimistic outlook, the Menninger Foundation's Psychotherapy Project 19 was published in which adequate and fair outcome criteria were established (The Health-Sickness Rating Scale). The importance of the transference relationship was roempharized 28 was the judgement of the experienced clinician and, in contrast to Strupp and Borgin's pesaimiow about the lack of effect of research on prectice, the findings of the Monninger study were put to use in the Menninger Clinic. Malan also found that his research 
findings at the Tavistock CIInic were put into practice there.

\section{Conciuston}

Strupp and Bergin man timos have spoken of the lack of impact of research on clinical practice. Much of this, says Malan, is due to a single factor, the "failure to design outcome criteria that do justice to the complexity of the human personality. "20 Once this 1 s achieved, as it was in the Menninger and Tavlstock studies, direct clinical application immediately follow. Maningful outcome criterla and meaningful variables, which presently heve to be based on clinfcal judgement, are necessary in Malan's opinion. But he also points out that we must be candid in Identifylng not only which therapies work with which type of patient, but also which therapies do not work with particular types of patients. We must not be overly depreseed by negative rindings, but rather proceed to look for meaning $\mathrm{nl}$ outcome criteria and ways of applying research to practice. Finally the question Malan asks is "where are the researchers to cowe from?" 


\section{CONGLUSIONS AND RECOMQIENDATIONS}

From our analysis we found that most clients changed in a positive direction, but not significantly. Therefore, statistically, more of the self raters tended to see themselves a. Improved than the Informants did; wore self and informant raters tended to agree on the post-PARS than on the pre-PARS.

Rogarding the research design, we found that the plan to admin1oter the post-PARS after three months of therapy was unrealistic in view of the pattern of client termination (see Table VIII-Appendix C, pago 35). Also, more date was lost than was anticipated and mailed responses are not dependable. Ellsworth cited this as one of the major technical problems when using an informant away from the treatment setting. 21 We feel it would be valuable if some alternate method could be used in gathering the data.

Another significant aspect of our research (and one that could well account for the lack of significant change scores) is the fact that there were no adequate controls fors (1) client variables (such as presenting problem and demographic factors) and (2) therapist variables (including treatment modality and individual therapist personality factors). From the Iiterature, we can $8 \theta 0$ the importance of having adequate controls on these factors, and the effect that Iumping the data together has on the mean for net change. Further, the wide variation in change scores that we found within groups in our analysis of variance could be a roflection of what was strongly emphasized in the 
literature: some clients got signiflcantly better and some significantly worse in therapy depending on who is doing the therapy and what kind of therapeutic modality 18 omployed. We feel that this is an important issue, and one area with which our research project did not deal.

In this study we set out to answer three questionss what effect does treatmont at the Delaunay Institute for Mental Hoalth have on its clients, is the PARS questionnaire a viable research tool for Delaunay use, and should it be retained? Unfortunately, we cannot give a decisive answer to the first of these questions. Due to methodological difflculties, we were forced to base our study on a relatively small group of data. We did find an encouraging trend toward positive change, but the figures were not significant. We predict, however, that if more adequate controls on variables wre used in the future, more significant results would be obtained along the lines of those found in the literature. Some clients would Improve more than others; some would get worses and some types of therapy would be wore effoctive than others with certain clients.

In light of this, we recomend the continuation of research efforts using the PARS questionnaire but with greater emphasis on controlling alient and thorapist variables. This is imperative. We would 2lso advocate periodic sampling and testing of clients with follow-up studies, rather than testing every new client.

Further, we see a glaring need for more complete and accurate colleotion of data by Delaunay.

We would hope the Delaunay (Ideally with the active involvement of therapiats) would some day attempt to develop a more conclse rating 
scale to measure treatment effectiveness which might obtain satisfactory results and be less complicated to administer and score than the PARS. In such a rating scale, perhaps more reliance could be placed on therapist ratings of client improvement if these could be put into quantiflable terms. Wo feel that if the agency were supportive of critical self examination, porhaps this would inspire individual therapists to take it upon themselves to do more research on their own treatment methods and their effectiveness. Therapists could then determine where they succeed and where they fall (whow they are helping and whom they are not) without necessarily needing to worry about how they measure up against other therapists within the clinic who may or may not have different philosophical and practical treatment approaches than they. Lastly, we urge that findings from research be used by therapists in their practice, both for their own professional betterment and for the welfare of the clients. Otherwise, the ethics of data collection and resarch without corresponding application to prectice are questionable. 
$I_{L}$. Wilkins, as clted in the PARS Manual, which was developed by Arylord L. Thorne, Ph.D., Oregon College of Education, Teaching Research Division, Monmouth, Oregon, 1968. Available through the Oregon State Mental Health Division.

${ }^{2}$ Robert B. Flsworth, "Consumer Feedback in Measuring Effectiveness of Mental Health Programs," Handbook of Evalustion Research, ed. Quttentag and Struening, in press.

3R. B. Ellsworth, et al., "Hospital and Community Adjustment as Porceived by Psychiatric Patients, Their Families and Staff," Journal of Consulting and Clinical Paychology, 32, No. 5 (1968), Part 2 (monograph supplement).

4Gaylord L. Thorne, PARS Manual.

5Davld H. Malan, "The Outcome Problem in Psychotherapy Research, A Historical Review, "Archives of Genersl Psychiatsy, 29 (December 1973), 719-729.

$$
\begin{aligned}
& 6 \text { Malan, p. } 719 . \\
& 7 \text { Malan, p. } 719 . \\
& 8_{\text {Malan, p. } 719 .} \\
& 9 \text { Malan, p. } 720 . \\
& 19_{\text {Malan, p. } 720 .} \\
& 11_{\text {Malan, p. } 721 .} \\
& 12_{\text {Malan, p. } 721 .} \\
& 13 \text { Malan, p. } 721 . \\
& 14 \text { Malan, p. } 721 . \\
& 15 \text { Malan, p. } 721 . \\
& 16 \text { Malan, p. } 722 . \\
& 17_{\text {Malan, p. } 724 .} \\
& 18_{\text {Malan, p. } 725 .} \\
& 19 \text { Malan, p. } 719 .
\end{aligned}
$$


20Malan, p. 728.

21EIlaworth, "Consumer Feedback," pp. 25-28. 


\section{A SRLECTED BIBLIOQRAPHY}

Elloworth, R. B., et al. "Hospital and Community Adjustment as Percelved by Psjchiatric Pationts, Their Families and Staff." Journal of Consulting and Clinical Psrcholory, 32, No. 5 (1968), Part 2 (monograph supplement).

Bllsworth, Robert B. "Conouwer Feedback in Measuring Effectiveness of Mental Health Programs." Hendbook of Evaluation Research.

Ed. Guttentag and Struening. In press.

Malan, David H. "The Outcon Problem in Psychotherapy Research, A Historical Reviow." Archives of General Prychiatry, 29 (December 1973), 719-729.

Thorne, Gaylord I. PARS Kanual. 1968. Avallable through the Oregon State Mental Health Difision. 
APPENDIX 
APPEARIX A

Mr. John Jones

Address

Portland, Oregon

Dear Mr. Jones:

Delaunay Institute is conducting research to determine the effect of its treatment mothods. As a former client wo are interested in how your experfence with this agency affocted you. As you recall, you filled out a brief questionnaire when you first came to Dolaunay Institute. At that time you indicated your willingness to complete another at a later date. Now wo would appreciate it if you would take a fow minutes to complete the enclosed questionnaire. We will be using your responses as data to doternine what impact wo have on our clients and also whother this mothod is offoctive in moasuring treatment results. Your response will be completely confldential and will be used only for the stated purpose. Client names will not be used after this contact. Your cooperation 1s essential in order that we may ovaluate our program.

Please complete the questionnaire as soon as possible. We will be contecting you early in December to make arrangements to plck up the completed questionnaire. Please foel free to contact Delaunay Institute if you have any questions regarding this matter.

Again your cooperation will be greatly appreciated.

Sincorely,

Oary Sint th and Joanette Finley 
APPENDIX B

TABLE III

PROPORTION OF RATERS WHO SAW

PRE-POST IMPROVEMENT

\begin{tabular}{|c|c|c|c|c|}
\hline PARS Factor & $\begin{array}{l}\text { Self } \\
(\operatorname{male})\end{array}$ & $\begin{array}{l}\text { Other } \\
\text { (male) }\end{array}$ & $\begin{array}{c}\text { Self } \\
(\text { female })\end{array}$ & $\begin{array}{c}\text { Other } \\
\text { (female) }\end{array}$ \\
\hline $\begin{array}{l}\text { Interpersonal } \\
\text { Involvement }\end{array}$ & .63 & .25 & .67 & .50 \\
\hline Agl tation-Depression & .63 & .63 & .90 & .70 \\
\hline Confusion & .88 & .63 & .80 & .30 \\
\hline Outside Social & .75 & .50 & .82 & .18 \\
\hline Household Management & $-\infty$ & $-\infty$ & .90 & .50 \\
\hline Alcohol & .75 & .13 & .67 & .44 \\
\hline Anxioty & .75 & .38 & -- & $-\infty$ \\
\hline Employment & .50 & .75 & .67 & .67 \\
\hline Parenthood Skills & .67 & .80 & .88 & .63 \\
\hline $\begin{array}{l}\text { Average } \% \text { who Rated } \\
\text { Improvement on } \\
\text { All Factors }\end{array}$ & .69 & .51 & .78 & .49 \\
\hline
\end{tabular}


APPEFDIX B

TABIE IV

NET POSITIVE OR NEGATIVE CHAHGS AS RATSD BI YAIE AND FEMAIS SBIF AND INFOPAANT

\begin{tabular}{|c|c|c|c|c|c|c|c|}
\hline & \multicolumn{3}{|c|}{ Male $(n=8)$} & \multicolumn{4}{|c|}{ Fenale $(n=11)$} \\
\hline PARS Factor & Self & Informant & $t$ & Self & & Informant & t \\
\hline $\begin{array}{l}\text { Interpersonal } \\
\text { Inrolvenent }\end{array}$ & $\begin{array}{l}\bar{x}=+.75 \\
s=4.73\end{array}$ & $\begin{array}{l}\bar{x}=-.25 \\
8=5.97\end{array}$ & .35 n. 8 & $\begin{array}{l}\bar{x}=+2.9 \\
s=5.3\end{array}$ & $(n=10)$ & $\begin{array}{l}\bar{x}=+.30 \\
\bar{s}=4.70\end{array}$ & $.76 \mathrm{n.s.}$ \\
\hline Agitation-Depression & $\begin{aligned} \bar{x} & =+4.75 \\
s & =8.93\end{aligned}$ & $\begin{aligned} \bar{x} & =-2.00 \\
s & =4.84\end{aligned}$ & $1.30 \mathrm{n.}$. & $\begin{array}{l}\bar{x}=+7.18 \\
s=7.7\end{array}$ & & $\begin{array}{l}\bar{x}=+3.50 \\
s=3.38\end{array}$ & $1.37 \mathrm{n.s}$ \\
\hline Confusion & $\begin{array}{l}\bar{x}=+6.38 \\
s=7.55\end{array}$ & $\begin{array}{l}\bar{x}=+1.50 \\
\bar{s}=5.52\end{array}$ & $1.38 \mathrm{n.s}$ & $\begin{array}{l}\bar{x}=+4.5 \\
8=5.55\end{array}$ & & $\begin{array}{l}\bar{x}=-.90 \\
\boldsymbol{s}=4.35\end{array}$ & 2.38 \\
\hline Outside Social & $\begin{array}{l}\bar{x}=+4.38 \\
s=4.26\end{array}$ & $\begin{array}{l}\bar{x}=+.25 \\
8=2.15\end{array}$ & 2.31 & $\begin{array}{l}\bar{x}=+1.18 \\
8=2.72\end{array}$ & & $\begin{aligned} \bar{x} & =+.36 \\
z & =1.96\end{aligned}$ & .77 n. s. \\
\hline Household Managewent & $---\infty---\infty$ & $\cdots-$ & $\cdots-\infty$ & $\begin{array}{l}\bar{x}=+2.75 \\
s=4.8\end{array}$ & $(n=8)$ & $\begin{array}{l}\bar{x}=+2.6 \\
\bar{x}=3.85\end{array}$ & .07 n. 8 . \\
\hline Alcohol & $\begin{array}{l}\bar{x}=+2.75 \\
s=5.53\end{array}$ & $\begin{array}{l}\bar{x}=0 \\
s=3.74\end{array}$ & $1.09 \mathrm{n.8}$ & $\begin{array}{l}\bar{x}=+2.0 \\
s=6.11\end{array}$ & & $\begin{array}{l}\bar{x}=-.56 \\
s=4.32\end{array}$ & $1.04 \mathrm{n.}$. \\
\hline Anxiety & $\begin{array}{l}\bar{x}=+3.00 \\
s=3.39\end{array}$ & $\begin{array}{l}\bar{x}=0 \\
s=4.27\end{array}$ & $1.46 \mathrm{n.s}$ & $\cdots$ & & $---0-0--$ & $-\infty-\infty-\infty-\infty$ \\
\hline
\end{tabular}


APPENDIX B

TARTE V

SELF AND INFORMANT PRB-POST RATIMGS

ON MALE CLIENTS

\begin{tabular}{|c|c|c|c|c|c|c|c|c|c|}
\hline \multirow[b]{2}{*}{ PARS Factor } & \multicolumn{4}{|c|}{ Solf Ratings } & \multicolumn{5}{|c|}{ Informant Ratings } \\
\hline & & Pre & Post & $t$ & & Pre & Post & & $t$ \\
\hline $\begin{array}{l}\text { Interpersonal } \\
\text { Imrolvement }\end{array}$ & $(n=8)$ & $\begin{array}{l}\bar{x}=35.00 \\
z=3.84\end{array}$ & $\begin{array}{r}35.75 \\
3.26\end{array}$ & .39 n. s. & $(n=8)$ & $\begin{array}{l}\bar{x}=34.37 \\
s=6.63\end{array}$ & $\begin{array}{r}34.12 \\
5.08\end{array}$ & .07 & n. 8. \\
\hline Agitation-Depression & $(n=8)$ & $\begin{array}{l}\bar{x}=25.12 \\
s=6.78\end{array}$ & $\begin{array}{r}20.37 \\
3.38\end{array}$ & $1.66 \mathrm{n.8}$. & $(n=8)$ & $\begin{array}{l}\bar{x}=20.87 \\
s=6.18\end{array}$ & $\begin{array}{r}21.12 \\
7.25\end{array}$ & .07 & n. 8. \\
\hline Confrision & $(n=8)$ & $\begin{array}{l}\bar{x}=27.87 \\
s=5.13\end{array}$ & $\begin{array}{r}21.50 \\
5.12\end{array}$ & 2.33 & $(n=8)$ & $\begin{array}{l}\bar{x}=25.50 \\
s=4.54\end{array}$ & $\begin{array}{r}24.00 \\
5.00\end{array}$ & .59 & n. 8 . \\
\hline Anxiety & $(n=8)$ & $\begin{array}{l}\bar{x}=16.62 \\
s=3.67\end{array}$ & $\begin{array}{r}12.25 \\
3.85\end{array}$ & 2.18 & $(n=8)$ & $\begin{array}{l}\bar{x}=23.25 \\
s=11.92\end{array}$ & $\begin{array}{r}11.75 \\
4.60\end{array}$ & 2.39 & \\
\hline Alcohol & $(n=8)$ & $\begin{array}{l}\bar{x}=13.75 \\
s=4.70\end{array}$ & $\begin{array}{r}71.00 \\
3.32\end{array}$ & 1.27 n. 8. & $(n=8)$ & $\begin{array}{l}\bar{x}=11.12 \\
s=5.67\end{array}$ & $\begin{array}{r}11.12 \\
2.99\end{array}$ & 0 & n. s. \\
\hline Outside Social & $(n=8)$ & $\begin{array}{l}\bar{x}=9.37 \\
s=3.96\end{array}$ & $\begin{array}{r}12.25 \\
4.19\end{array}$ & $1.32 \mathrm{n.} 8$. & $(n=8)$ & $\begin{array}{l}\bar{x}=9.12 \\
s=3.26\end{array}$ & $\begin{array}{l}9.12 \\
3.26\end{array}$ & 0 & n. 3 . \\
\hline Employment & $(n=6)$ & $\begin{array}{l}\bar{x}=21.33 \\
s=6.49\end{array}$ & $\begin{array}{r}21.50 \\
7.58\end{array}$ & $.03 \mathrm{n.s}$ & $(n=4)$ & $\begin{array}{l}\bar{x}=23.75 \\
8=3.95\end{array}$ & $\begin{array}{r}25.25 \\
4.94\end{array}$ & .41 & n. 8. \\
\hline Parenthood Skdlls & $(n=6)$ & $\begin{array}{l}\bar{x}=20.66 \\
s=2.56\end{array}$ & $\begin{array}{r}21.83 \\
1.67\end{array}$ & $.86 \mathrm{n.s.}$ & $(n=5)$ & $\begin{array}{l}\bar{x}=21.20 \\
s=5.71\end{array}$ & $\begin{array}{r}23.60 \\
3.71\end{array}$ & .70 & n. s. \\
\hline
\end{tabular}




\section{APPENDIX B}

TABIB VI

SELF AND INFORANT PRE-POST RATINGS ON FBrute CLIBNTS

\begin{tabular}{|c|c|c|c|c|c|c|c|c|c|c|}
\hline \multirow[b]{2}{*}{ PARS Factor } & \multicolumn{5}{|c|}{ Self Ratings } & \multicolumn{5}{|c|}{ Informant Ratings } \\
\hline & & Pre & Post & & $t$ & & Pre & Post & & $t$ \\
\hline $\begin{array}{l}\text { Interpersonal } \\
\text { Imolvement }\end{array}$ & $(n=10)$ & $\begin{array}{l}x=32.90 \\
s=6.43\end{array}$ & $\begin{array}{r}37.20 \\
5.95\end{array}$ & 1.47 & n. 8. & $(n=10)$ & $\begin{aligned} \bar{x} & =34.90 \\
s & =7.51\end{aligned}$ & $\begin{array}{r}35.20 \\
6.94\end{array}$ &.$\infty$ & n. $\mathbf{s}$. \\
\hline Agitation-Depression & $(n=11)$ & $\begin{array}{l}\bar{x}=33.18 \\
.=3.81\end{array}$ & $\begin{array}{r}26.18 \\
6.85\end{array}$ & 2.84 & & $(n=10)$ & $\begin{array}{l}\bar{x}=28.80 \\
z=6.92\end{array}$ & $\begin{array}{r}25.30 \\
6.72\end{array}$ & 1.29 & n. $\mathbf{s}$. \\
\hline Confusion & $(n=11)$ & $\begin{aligned} \bar{x} & =26.81 \\
s & =5.34\end{aligned}$ & $\begin{array}{r}22.09 \\
3.95\end{array}$ & 2.25 & & $(n=10)$ & $\begin{array}{l}\bar{x}=21.00 \\
s=6.31\end{array}$ & $\begin{array}{r}21.90 \\
4.48\end{array}$ & .35 & n. s. \\
\hline Alcohol & $(n=11)$ & $\begin{array}{l}\bar{x}=6.27 \\
s=3.24\end{array}$ & $\begin{array}{l}4.54 \\
1.82\end{array}$ & .82 & n. s. & $(n=11)$ & $\begin{array}{l}\bar{x}=5.45 \\
s=3.27\end{array}$ & $\begin{array}{r}2.61 \\
.82\end{array}$ & .27 & n. $s$. \\
\hline Outside Social & $(n=8)$ & $\begin{array}{l}\bar{x}=11.37 \\
s=3.70\end{array}$ & $\begin{array}{r}13.37 \\
3.42\end{array}$ & 1.09 & n. 8. & $(n=10)$ & $\begin{array}{l}\bar{x}=11.80 \\
s=4.80\end{array}$ & $\begin{array}{r}13.40 \\
4.07\end{array}$ & .83 & n. $\mathbf{s}$. \\
\hline Housebold Management & $(n=11)$ & $\begin{array}{l}\bar{x}=27.90 \\
s=7.71\end{array}$ & $\begin{array}{r}31.09 \\
8.43\end{array}$ & .88 & n.s. & $(n=9)$ & $\begin{array}{l}\bar{x}=31.00 \\
s=5.43\end{array}$ & $\begin{array}{r}30.66 \\
7.35\end{array}$ & .16 & n. s. \\
\hline Exploywent & $(n=3)$ & $\begin{array}{l}\bar{x}=10.66 \\
x=4.49\end{array}$ & $\begin{array}{r}24.66 \\
3.09\end{array}$ & 3.66 & & $(n=3)$ & $\begin{array}{r}\bar{x}=17.00 \\
s=6.48\end{array}$ & $\begin{array}{r}17.00 \\
3.55\end{array}$ & 0 & n. $s$. \\
\hline Parenthood Skdlls & $(n=8)$ & $\begin{array}{l}\bar{x}=22.12 \\
s=2.54\end{array}$ & $\begin{array}{r}24.12 \\
3.55\end{array}$ & 1.22 & $n_{.} s_{\text {. }}$ & $(n=8)$ & $\begin{array}{l}\bar{x}=21.25 \\
s=3.79\end{array}$ & $\begin{array}{r}22.50 \\
3.24\end{array}$ & .66 & n. s. \\
\hline
\end{tabular}


APPENDIX B

TABLE VII

CORREILATION COERFICIENTS

BETWEBW RATERS

\begin{tabular}{|c|c|c|c|c|c|c|}
\hline PARS Factor & $\mathbf{n}$ & \multicolumn{2}{|c|}{$\begin{array}{c}\text { Male Clients } \\
\text { Self v8. Informant }\end{array}$} & $\mathbf{n}$ & \multicolumn{2}{|c|}{$\begin{array}{l}\text { Femalo Clients } \\
\text { Self v8. Informant }\end{array}$} \\
\hline $\begin{array}{l}\text { Interpersonal } \\
\text { Involvement }\end{array}$ & 8 & .20 & .47 & 9 & .68 & .75 \\
\hline Agitation & 8 & -.04 & .70 & 10 & .78 & .32 \\
\hline Confusion & 8 & .54 & .80 & 10 & -.08 & .00 \\
\hline Outside Social & 8 & .35 & .140 & 11 & .56 & .80 \\
\hline $\begin{array}{l}\text { Household } \\
\text { Management }\end{array}$ & -- & $-\infty$ & $\cdots$ & 7 & .84 & .18 \\
\hline Alcohol & 8 & .88 & .87 & 9 & .45 & .93 \\
\hline Anxiety & 8 & .72 & .54 & - & $\cdots$ & $\cdots$ \\
\hline Employment & 5 & .91 & .88 & 2 & .89 & 1.00 \\
\hline Parenthood Skills & 5 & .56 & .88 & 7 & .37 & -.37 \\
\hline $\begin{array}{l}\text { Average } \\
\text { Correlations }\end{array}$ & & .51 & .69 & & .56 & .45 \\
\hline
\end{tabular}

*unwelghted 


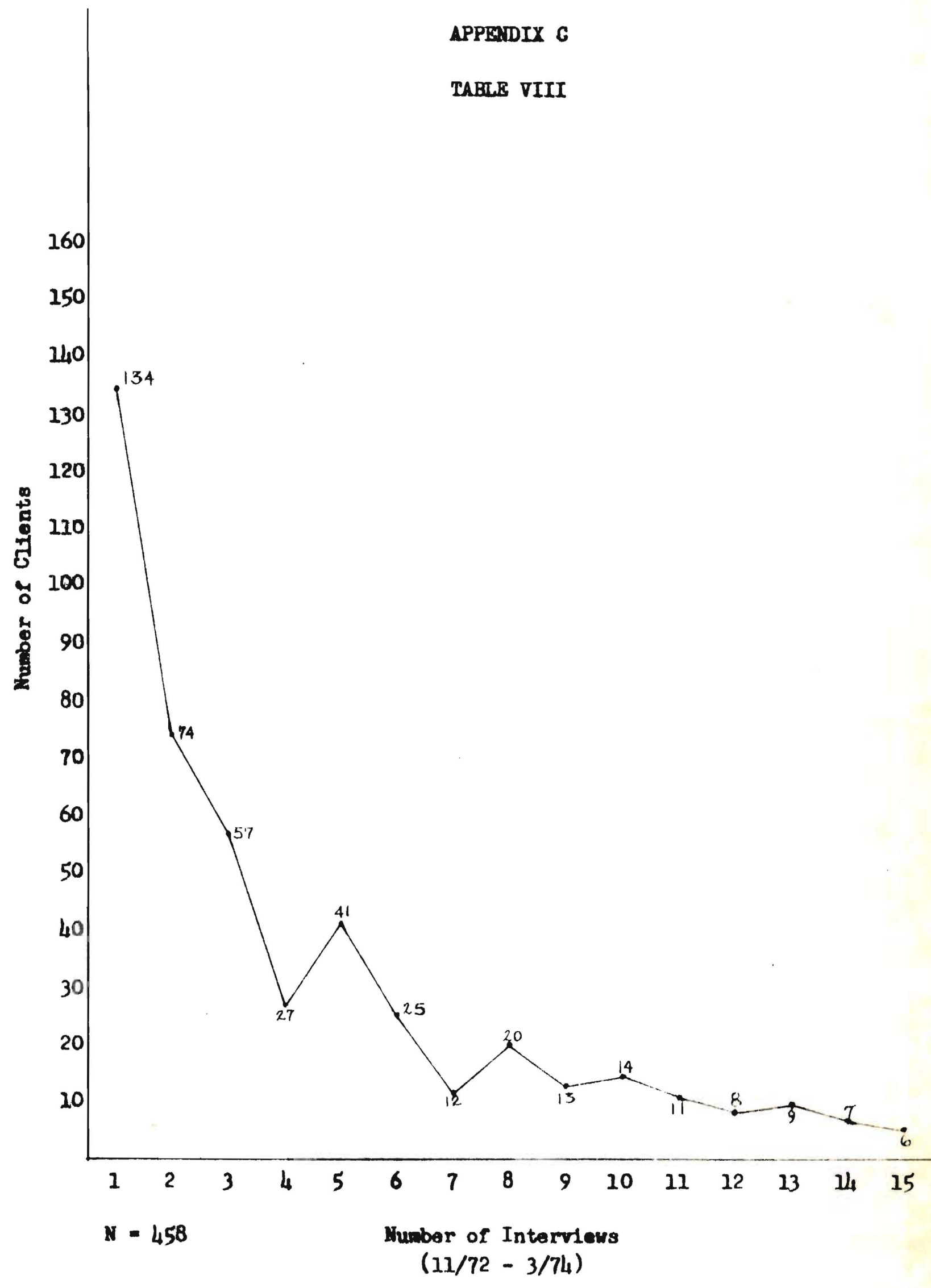

